\title{
From the Editor:
}

Slavic Review publishes letters to the editor with educational or research merit. Where the letter concerns a publication in Slavic Review, the author of the publication will be offered an opportunity to respond. Space limitations dictate that comment regarding a book review should be limited to one paragraph; comment on an article should not exceed 750 to 1,000 words. The editor encourages writers to refrain from ad hominem discourse.

D.P.K.

\section{To the Editor:}

The article by Klaus-Peter Friedrich, "Collaboration in a 'Land without a Quisling': Patterns of Cooperation with the Nazi German Occupation Regime in Poland during World War II" (Slavic Review 64, no. 4) addresses an important topic. The author's scholarly apparatus gives the impression of the proverbial German Gründlichkeit, yet in the final analysis, Friedrich's handling of this question raises doubts about his objectivity and methodology.

In the first place, I miss a clear definition of collaboration. Calling it a social and ideological phenomenon is too vague. A much more satisfactory definition was provided by one of the leaders of the Polish underground: "Voluntary cooperation with the enemy to the detriment of the country or fellow citizens" (Stefan Korbonski, The Polish Underground State: A Guide to the Underground, 1939-1945, 1978, 140).

Friedrich seems to try so hard to make the point that "collaboration" was not a marginal phenomenon that he omits or downplays different views. He asserts (on what grounds?) that Jan T. Gross's book on the General Gouvernement, which he cites several times, has been largely ignored by Polish historiography. He mentions the article by Bernard Wiaderny as proof of Polish politicians' attempted offers of collaboration, but seems unaware of the discussion that followed it (Zeszyty Historyczne, no. 143 [2003]: 21534 and no. 144 [2003]: 232) and that brought out Wiaderny's many flaws. One looks in vain for any reference to another serious debate among historians: "Kolaboracja i historia," Arcana, no. 51/52 [2003]: 13-69. Similarly, in his several mentions of Jedwabne, Friedrich seems only to be familiar with Gross's book on the subject, but not the huge two-volume collection of studies and documents entitled Wokót Jedvabmego, edited by Paweł Machcewicz and Krzysztof Persak (2002). Finally, one wonders why the major bookchronicle by a prominent member of the underground Żegota (which helped the Jews), Władysław Bartoszewski, 1859 Dni Warszauny (1974) is ignored.

I wish that Friedrich who cites so many sources would also have stressed more clearly the significance of the date of a given publication. Given Polish conditions, it makes quite a difference when a book or article was published. The reader may not be fully aware of this.

As I said at the beginning of this letter, I fear that Friedrich's presentation is not balanced or even-handed. When he speaks of "collaboration" by the Polish clergy he does not mention (even in a footnote) the large number of priests who perished at Nazi hands. Is it really useful to give estimates of "collaborators" that range from 7,000 to 1 million rather than admit that one does not know and that it depends on what is meant by collaboration? And when speaking of the number of Jews rescued-and it is not clear to me how Friedrich arrived at his final figure-should one not also speculate how many Poles had to be involved to save one Jew? John Connelly makes this point in his comments in the same issue ("Why the Poles Collaborated So Little-And Why That Is No Reason for Nationalist Hubris," 780). And let us recall once again that aiding Jews was punishable by death only in Poland and in the occupied parts of the USSR. Last but not least, if "collab- 